\title{
GAMBARAN KESEHATAN REPRODUKSI SISWA SMA DI SMAN I MENGWI
}

\section{(Description Of High School Students' Reproductive Health At SMAN I Mengwi)}

\author{
N.Nuartini ${ }^{*}$, LP Kartiningsih ** \\ $\left.{ }^{*}\right),{ }^{* *}$ Institut Teknologi dan Kesehatan Bali \\ Jalan Tukad Balian No. 180 Renon Denpasar
}

\begin{abstract}
ABSTRAK
Latar belakang: Indikator kesehatan salah satunya adalah kesehatan reproduksi remaja putri. Hal ini sangat penting mengingat kesehatan reproduksi dapat mempengaruhi terlahirnya generasi penerus yang berkualitas. SMAN I Mengwi merupakan salah satu Institusi pendidikan yang mendidik Siswa pada proses perkembangan reproduksi. Belum diketahui dengan pasti bagaimana gambaran kesehatan Siswa di sekolah ini sehingga perlu dilakukan penelitian untuk mengetahui gambaran lebih lanjut. Penelitian ini bertujuan untuk mengetahui secara mendalam gambaran kesehatan reproduksi Siswa SMA di SMAN I Mengwi

Metode :Rancangan penelitian ini adalah qualitative eksploratif. Data dikumpulkan melalui teknik wawancara mendalam terhadap 10 informan terkait dan dianalisis secara tematik.

Hasil: Keseluruhan informan penelitian ini memiliki persepsi bahwa kesehatan reproduksi adalah sesuatu yang sangat penting dan harus dijaga. Gambaran kesehatan reproduksi siswa SMAN I Mengwi cukup baik dan mampu merawat kesehatan reproduksi mereka dengan baik hanya saja masih dietmukan tingkat konsumsi tablet besi yang masih kurang sehingga masih ada keluhan letih dan lesu pada saat mengalami menstruasi.

Simpulan: Secara umum gambaran kesehatan reproduksi siswa SMAN I Mengwi Cukup baik dilihat dari segi pengetahuan dan pemahaman siswa menjaga kesehatan reproduksinya walaupun masih kurang dalam konsumsi tablet besi. Untuk itu disarankan kepada pihak terkait untuk membantu peningakatan cakupan konsumsi tablet besi pada siswa SMA untuk pencegahan anemia terutama pada saat menstruasi.
\end{abstract}

Kata Kunci: Kesehatan Reproduksi, Siswa SMA

\section{ABSTRACT}

Background: One of the health indicators is the reproductive health of adolescent girls. This is very important considering that reproductive health can affect the birth of a quality next generation. SMAN I Mengwi is one of the educational institutions that educate students in the process of reproductive development. It is not known with certainty how the health condition of students in this school is so it is necessary to do research to find out more about this condition. This study aims to find out in depth the description of reproductive health of high school students at SMAN I Mengwi.

Methods: The design of this research is qualitative exploratory. Data were collected through in-depth interviews with 10 related informants and analyzed thematically.

Result: All of the informants of this research have the perception that reproductive health is something that is very important and must be maintained. The description of reproductive health of SMAN I Mengwi students is quite good and able to take care of their reproductive health well, but it is still found that the level of consumption of iron tablets is still 
lacking so that there are find some complaints of fatigue and lethargy during menstruation.

Conclusion: In general, the picture of the reproductive health of SMAN I Mengwi students is quite good in terms of knowledge and understanding of students maintaining their reproductive health, although they are still lacking in consuming iron tablets. For this reason, it is recommended to related parties to help increase the coverage of iron tablet consumption in high school students for the prevention of anemia, especially during menstruation.

Keywords: Reproductive Health, High School Students

\section{LATAR BELAKANG}

Kesehatan merupakan suatu keadaan terbebas dari penyakit baik secara fisik maupun mental dan produktif (Kemenkes RI, 2009). Indikator kesehatan salah satunya adalah kesehatan ibu dan anak terutama pada angka kematian ibu dan angka kematian bayi baru lahir serta kesehatan reproduksi remaja putri. Khusus untuk kesehatan reproduksi remaja putri sangat penting mengingat kesehatan reproduksi dapat mempengaruhi terlahirnya generasi penerus yang berkualitas. Untuk menyikapi hal itu sejak Tahun 2003 Kementerian Kesehatan Republik Indonesia mengembangkan sebuah model pelayanan kesehatan reproduksi remaja yang dikenal dengan pelayanan kesehatan peduli remaja (PKPR) dengan kegiatan utama yang dilakukan adalah pelayanan konseling dan meningkatkan kemampuan remaja dalam pendidikan keterampilan hidup bersih dan sehat (PHBS).

Kesehatan reproduksi remaja tidak hanya mencakup kesehatan organ reproduksi saja tapi juga mencakup bagaimana organ-organ tersebut mampu berfungsi dengan optimal. Hal ini harus didukung oleh berbagai faktor seperti nutrisi dan prilaku hidup bersih dan sehat. Hasil Riskesdas Tahun 2018 menunjukan bahwa terdapat $36,3 \%$ remaja putri yang mengalami kekurangan energi kronis, masih terdapat $23,8 \%$ remaja yang tidak mengkonsumsi tablet besi untuk kecukupan zat besi mereka. Hal ini dipertegas dengan data dari $76,2 \%$ remaja yang mengkonsumsi tablet besi $98,6 \%$ mengkonsumsi tablet besi kurang dari standar yaitu 52 tablet dan hanya $1,4 \%$ yang mengkonsumsi tablet besi sesuai standar kesehatan. Dampak yang ditimbulkan adalah meningkatnya ancaman kekurangan gizi dan zat besi dini pada remaja putri yang sering menimbulkan anemia dan gangguan reproduksi yang lainnya. Selain itu masih tingginya tingkat obsitas pada remaja serta belum idealnya proporsi tubuh terutama pada remaja putri meningkatkan resiko gangguan kesehatan reproduksi remaja putri tersebut.
SMAN I Mengwi merupakan salah satu institusi yang mendidik Siswa dengan rentang usia Siswa ini berkisar antara 18-20 tahun. Rentang usia ini merupakan rentang usia yang masih rentan mengalami masalah kesehatan reproduksi baik secara anatomi maupun fisiologi. Secara khusus belum pernah dilakukan penelitian tentang situasi kesehatan reproduksi pada Siswa ini. Oleh sebab itu pada penelitian ini akan diteliti lebih lanjut tentang gambaran kesehatan reproduksi Siswa SMA di SMAN I Mengwi.

\section{METODE PENELITIAN}

Penelitian ini menggunakan studi kualitatif dengan pendekatan ekploratif. Peneliti berusaha menggali lebih dalam informasi yang ada dengan mendengarkan dan membuat tema dari data yang didapat terhadap orangorang yang terlibat dalam situasi tertentu (Creswell, 2003). Penelitian ini berusaha memahami secara mendalam tentang gambaran kesehatan reproduksi siswa SMA di SMAN I Mengwi. Data dikumpulkan melalui teknik wawancara mendalam dengan menggunakan pedoman wawancara terbuka terhadap informan yang diteliti berjumlah 10 orang yang terdiri dari 7 orang informan siswa SMA, 2 orang informan dari pihak sekolah dan 1 orang informan dari keluarga siswa. Partisipan dipilih dengan tehnik purposive sampling.

Partisipan penelitian diberikan informasi sebelum dilakukan wawancara dan diminta menandatangani lembar persetujuan untuk berpartisipasi dalam penelitian. Partisipan tidak diberikan upah sebagai imbalan. Wawancara dilakukan secara online melalui Wa Vidio Call untuk mengurangi penularan Covid-19. Analisis data dilakukan dengan membuat kode, kategori dan tema utama yang disajikan pada bagian hasil

\section{HASIL DAN PEMBAHASAN}

Penelitian ini menemukan Secara umum sebagian besar informan utama pada penelitian ini berada pada rentang

Jurnal Riset Kesehatan Nasional hal. 132 
usia remaja yaitu 16-17 tahun dan duduk pada kelas XI. Karakteristik informan meliputi berat badan, tinggi badan, lingkar lengan dan lingkar panggul siswa menunjukkan hasil pengukuran masih berada pada rentang normal. Sebagian besar informan memiliki keluhan letih dan lesu pada saat mengalami menstruasi. Seluruh informan utama pada penelitian memiliki persepsi bahwa kesehatan reproduksi merupakan sesuatu yang sangat penting karena hal ini menyangkut semua organ reproduksi dan fungsinya. Keseluruhan informan utama pada penelitian ini memiliki tingkat pengetahuan yang cukup baik tentang kesehatan reproduksi, memiliki cara-cara tersendiri dalam merawat kesehatan organ reproduksinya. Namun masih ditemukan kurangnya minat informan untuk mengkonsumsi tablet besi.

Hasil penelitian ini selanjutnya dikelompokkan ke dalam tiga tema tema sentral yaitu tema pertama persepsi siswa SMAN I Mengwi tentang kesehatan reproduksi. Tema kedua adalah gambaran kesehatan reproduksi siswa SMAN I Mengwi dan tema yang ketiga adalah pengalaman siswa SMAN I Mengwi dalam merawat kesehatan reproduksinya. Tema-tema ini dijabarkan sebagai berikut.

\section{Persepsi Siswa SMAN I Mengwi Tentang Kesehatan Reproduksi}

Seluruh informan utama pada penelitian memiliki persepsi bahwa kesehatan reproduksi merupakan sesuatu yang sangat penting karena hal ini menyangkut semua organ reproduksi dan fungsinya. Hal ini seharusnya diajarkan sejak dini karena menyangkut tentang proses melanjutkan keturunan. Hal ini seperti yang disampaikan informan di bawah ini:

"Kesehatan reproduksi adalah hal yang sangat penting, terutama pada remaja. Sebab masa remaja adalah waktu terbaik untuk membangun kebiasaan baik menjaga kebersiha yang bisa menjadi aset dalam jangka panjang. Reproduksi bisa diartikan sebagai proses kehidupan manusia dalam menghasilkan kembali keturunan. Karena definisi yang terlalu umum tersebut, seringnya reproduksi hanya dianggap sebatas masalah seksual atau hubungan intim. Alhasih, banyak orang tua yang merasa tidak nyaman untuk membicarakan masalah tersebut pada remaja. Padahal, kesehatan reproduksi, terutama pada remaja merupakan kon- disi sehat yang meliputi sistem, fungsi, dan proses reproduksi" (R001,R002, R004,R005)

"Pada dasarnya kesehatan reproduksi merupakan unsur yang dasar dan penting dalam kesehatan umum, baik untuk laki-laki dan perempuan. Selain itu, kesehatan reproduksi juga merupakan syarat ensensial bagi semua kalangan baik itu remaja, anak- anak maupun orang dewasa.Pendapat saya mengenai kesehatan reproduksi remaja adalah kesehatan reproduksi remaja merupakan suatu kondisi sehat yang menyangkut sistem, fungsi dan proses reproduksi yang dimiliki oleh remaja. Seharusnya sejak dini anak sudah diajarkan mengenai pendidikan seks seperti satuan terpisah antara laki- laki dan perempuan, bagaimana cara menjaga dan merawat alat reproduksinya, serta memberi larangan pada hal- hal yang dapat merusak kesehatam organ reproduksi"'(R003,R006,R007)

Pernyataan informan utama ini juga didukung oleh informan pendukung di bawah ini:

"Kesehatan reproduksi merupakan kondisi sehat yang meliputi sistem, fungsi, dan proses reproduksi dan hal ini merupakan suatu yang sangat penting. Hal ini sudah masuk dalam kurikulum sekolah." (P001,P002)

Kesehatan merupakan suatu keadaan terbebas dari penyakit baik secara fisik maupun mental dan produktif (Kemenkes RI, 2009). Indikator kesehatan salah satunya adalah kesehatan ibu dan anak terutama pada angka kematian ibu dan angka kematian bayi baru lahir serta kesehatan reproduksi remaja putri. Khusus untuk kesehatan reproduksi remaja putri sangat penting mengingat kesehatan reproduksi dapat mempengaruhi terlahirnya generasi penerus yang berkualitas. Untuk menyikapi hal itu sejak Tahun 2003 Kementerian Kesehatan Republik Indonesia mengembangkan sebuah model pelayanan kesehatan reproduksi remaja yang dikenal dengan pelayanan kesehatan peduli remaja (PKPR).

\section{Gambaran Kesehatan Reproduksi Siswa SMAN I Mengwi}

Keseluruhan informan utama pada penelitian ini memiliki tingkat pengetahuan yang cukup baik tentang kesehatan reproduksi yang meliputi ruang lingkup kesehatan reproduksi dan faktor-faktor resiko yang bisa

Jurnal Riset Kesehatan Nasional hal. 133 
menimbulkan ganguan pada kesehatan reproduksi remaja tersebut. Seperti yang disampaikan oleh informan di bawah ini:

"Secara sederhana, reproduksi berasal dari kata "re" yang berarti kembali dan "produksi" yang artinya membuat atau menghasilkan. Reproduksi bisa diartikan sebagai proses kehidupan manusia dalam menghasilkan kembali keturunan. kesehatan reproduksi merupakan keadaan kesehatan fisik, mental, dan sosial yang sangat penting untuk dimengerti oleh remaja, sehingga tidak melulu membahas mengenai hubungan seksual. (R002,R007)

"Kesehatan reproduksi remaja merupakan suatu kondisi sehat yang menyangkut sistem, fungsi dan proses reproduksi yang dimiliki oleh remaja. Pengertian sehat disini tidak semata-mata berarti bebas penyakit atau bebas dari kecacatan. Sehat yang dimaksud adalah sehat yang menyeluruh, meliputi aspek fisik, mental dan sosial dan bukan sekedar tidak adanya penyakit atau gangguan segala hal yang berkaitan dengan sistem reproduksi, fungsinya maupun proses reproduksi itu sendiri. Jadi dapat disimpulkan bahwa kesehatan reproduksi adalah suatu cara untuk pencegahan dan penyelesaian masalah kesehatan reproduksi meliputi kesehatan fisik, mental, sosial dan bukan sekedar tidak hanya konsultasi dan keperawatan yang berkaitan dengan reproduksi dan penyakit yang ditularkan melalui hubungan seks."(R003,R006)

Pemahaman tentang faktor resiko yang dapat menimbulkan gangguan pada organ reproduksi pada informan utama ini cukup baik seperti yang disampaikan oleh informan di bawah ini:

"Banyak hal yang bisa menimbulkan gangguan pada organ reproduksi, yang saya tahu seperti pergaulan bebas dan hubungan sex bebas, melakukan aborsi, terkena penyakit menular sex apalagi HIV. Belum lagi gangguan pada organ reproduksi itu sendiri. Makanya ini harus dijaga dengan baik". (R00, R004,R005)

Pernyataan informan utama ini didukung oleh informan pendukung yang menyatakan bahwa sekolah berusaha meningkatkan pemahaman siswa terhadap kesehatan reproduksi melalui memasukan beberapa mata pelajaran terkait kesehatan reproduksi ke dalam kurikulum pelajaran dan dibentuknya beberapa ekstrakurikuler yang bermuatan kesehatan reproduksi. Hal ini seperti yang disampaikan para informan ini:

"Kesehatan reproduksi siswa di sekolah ini sudah terlaksana dengan baik dan terpola dalam kurikulum. Usaha yang dilakukan untuk meningkatkan kesehatan reproduksi siswa di sekolah ini diantaranya Dibentuknya ektra kurikuler KSPAN (Kelompok siswa peduli aids dan narkoba) yang menggerakkan siswa untuk pencegahan aids dan penyalah gunaan narkoba. Memaksimalkan peran UKS, Kegiatan ekstra PMR. Hal-hal yang sering terjadi karena kurangnya sosialiasi dan edukasi adalah penyakit seksual menular, kehamilan di usia muda, hingga aborsi yang berakibat pada hilangnya nyawa remaja" (P001,P002)

"Pendapat saya tentang kesehatan reproduksi siswa di sekolah ini sudah terlaksana dengan baik karena telah diajarkan melalui pendidikan kesehatan reproduksi pada mata pelajaran biologi sesuai kurikulum yang berlaku serta beberapa program penyuluhan kesehatan reproduksi. Usaha yang dilakukan untuk meningkatkan kesehatan reproduksi siswa di sekolah ini yang saya tahu adalah dibentuknya ektrakurikuler KSPAN (Kelompok Siswa Peduli AIDS dan Narkoba) yang mewadahi siswa dalam mencegah AIDS dan penyalahgunaan narkoba." (P003)

\section{Pengalaman Siswa SMAN I Mengwi dalam Merawat Kesehatan Reproduksi}

Keseluruhan informan utama pada penelitian ini mengatakan memiliki cara dan pengalaman tersendiri dalam merawat kesehatan reproduksinya. Secara umum para informan ini merawat kesehatan reproduksi dengan cara rajin melakukan pembersihan organ reproduksi (Cebok) dengan tehnik dan cara yang sudah tepat., rajin mengganti celana dalam, rajin olah raga, makan-makanan yang bergizi, berusaha mengelola stress serta kontrol ke dokter jika mengalami keluhan dan gangguan yang menyangkut kesehatan reproduksi seperti telat menstruasi, keputihan dan yang lainnya. Salah satu temuan hasil penelitian yang menarik adalah sebagian besar informan utama ini ternyata tidak suka mengkonsumsi vitamin penambah darah dan ramuan yang bisa membantu menjaga kesehatan reproduksi mereka, hal ini sesuai dengan temuan data pada karakteristik informan yang sebagian besar mengalami kelu-

Jurnal Riset Kesehatan Nasional hal. 134 
keluhan letih dan lesu saat menstruasi. Hasil penelitian ini seperti yang disampaikan oleh informan di bawah ini:

"Sehabis Buang Air Besar (BAB) dan Buang Air Kecil (BAK) kita cebok dengan air bersih dan sebisa mungkin dari depan ke belakang karena yang kotor itu anus. Sebaiknya menggunakan handuk kering untuk mengeringkan. Dalam memilih celana dalam, saya memilih untuk mengenakan celana dalam berbahan katun supaya ada sirkulasi udara. Celana dalam juga harus sering diganti paling tidak dua kali dalam sehari $\mathrm{ka}$ rena keringat bisa membuat lembab. Saya pernah kontrol ke dokter sekali karena waktu itu saya telat menstruasi tetapi kata dokter hal itu wajar karena masih masa-masa awal menstruasi. Saya juga pernah berkonsultasi terkait nyeri saat datang bulan." (R001, R002, R005)

"Banyak cara yang bisa kita lakukan untuk menjaga kesehatan reproduksi kita, yang saya tahu seperti melakukan olahraga teratur selain meningkatkan kesehatan jantung dan pembuluh darah, olahraga juga bisa bermanfaat untuk menjaga kesehatan reproduksi, Hindari rokok Merokok, hindari minum alkohol minum alkohol. Berperilaku seksual secara sehat Berperilaku seksual yang sehat dengan menghindari aktivitas seksual berisiko untuk menghindari penyakit seksual dan makan bergizi serta hindari stress." (R003, R006)

"Saya jarang minum ramuan karena tidak cocok dengan rasanya. akhir-akhir ini saya jarang minum vitamin penambah darah karena rasanya seperti darah dan membuat mual dan memilih untuk menjaga pola makan." (R001,R004,R005)

Pihak sekolah sebenarnya sudah berupaya meningkatkan asupan vitamin penambah darah (tablet besi) pada siswa khususnya siswa perempuan dan deteksi dini gangguan kesehatan reproduksi yang terjadi dengan bekerjasama dengan pihak puskesmas dan lembaga terkait. Hal ini dilakukan untuk mencegah masih rendahnya caukpan konsumsi tablet besi pada siswa dan tingginya angka anemia pada remaja usia reproduktif. Hal ini seperti yang disampikan oleh informan pendukung di bawah ini:

Kami dari sekolah biasanya bekerjasama dengan berbagai pihak untuk melaksanakan pemeriksaan resiko kanker servick dan kanker payudara oleh petugas Puskesmas Mengwi. melakukan penyulu- han kesehatan reproduksi olek KPA (Komisi Penanggulangan Aids) Pemerintah Kabupaten Badung, posbindu. Rasanya pernah diberikan vitamin ke para siswa." (P001, P002)

Hasil penelitian ini sesuai dengan hasil Riskesdas Tahun 2018 yang menunjukkan bahwa terdapat $36,3 \%$ remaja putri yang mengalami kekurangan energi kronis, masih terdapat $23,8 \%$ remaja yang tidak mengkonsumsi tablet besi untuk kecukupan zat besi mereka. Hal ini dipertegas dengan data dari $76,2 \%$ remaja yang mengkonsumsi tablet besi 98,6\% mengkonsumsi tablet besi kurang dari standar yaitu 52 tablet dan hanya $1,4 \%$ yang mengkonsumsi tablet besi sesuai standar kesehatan. Dampak yang ditimbulkan adalah meningkatnya ancaman kekurangan gizi dan zat besi dini pada remaja putri yang sering menimbulkan anemia dan gangguan reproduksi yang lainnya.

\section{Refleksi Penelitian}

Usia remaja merupakan satu fase dalam tumbuh kembang manusia yang sangat penting karena pada saat ini remaja mengalami pertumbuhan dan perkembangan pada semua komponen tubuh baik secara fisik maupun fisiologis. Pada masa ini organ reproduksipun semakin megalami pematangan. Hal ini harus dijaga dengan baik dengan meningkatkan pengetahuan yang cukup dan memiliki pemahaman serta pengalaman yang baik dan benar tentang cara perawatan kesehatan reproduksi. Hasil penelitian ini menemukan gambaran kesehatan reproduksi siswa SMA Negeri I Mengwi cukup baik dan sudah cukup paham tentang cara menjaga kesehatan reproduksi mereka namun masih ditemukan kurangnya konsumsi tablet penambah darah (tablet besi) pada siswa perempuan karena parab informan cenderung tidak menyukai rasanya dan merasa mual jika mengkonsumsinya. Hal ini menyebabkan para informan sering mengeluh letih dan lesu saat megalami mensturuasi.

\section{SIMPULAN DAN SARAN Simpulan}

Secara umum informan pada penelitian ini memiliki persepsi bahwa kesehatan reproduksi merupakan sesuatu yang penting dan harus dijaga dengan baik. Hal ini harus diajarkan sejak dini pada remaja dan anakanak. Secara umum gambaran kesehatan reproduksi siswa SMA Negeri I Mengwi cukup

Jurnal Riset Kesehatan Nasional hal. 135 
baik dilihat dari segi karakteristik informan dan hasil wawancara mendalam. Para informan cukup memahami pengetahuan tentang kesehatan reproduksi dan cara menjaganya. Namun temuan yang cukup penting adalah masih kurangnya konsumsi tablet besi pada siswa perempuan karena cenderung tidak menyukai rasanya dan sering merasa mual saat meminum tablet besi tersebut sehingga sebagian besar informan masih mengeluh merasa letih dan lesu saat menstruasi.

\section{Saran}

Saran ditujukan kepada pada siswa, orang tua/wali dan pihak sekolah agar selalu berupaya meningkatkan cakupan pemberian tablet besi kepada para siswa karena hal ini sangat penting sebagai upaya pencegahan masih tingginya angka anemia zat besi pada para remaja khususnya siswa SMA.

\section{KEPUSTAKAAN}

Bungin,B.2012. Analisis Data Penelitian Kualitatif. Jakarta: Raja Grafindo. Persada

Creswell, J.W. 2003. Research Design: Qualitative, Quantitative and Mixed Methods Approaches. New Delhi: SAGE Publications
Depkes RI.2003. Indikator Indonesia Sehat 2010 dan Pedoman Penetapan Indikator Provinsi Sehat dan Kabupaten/ Kota Sehat. Jakarta.

Departemen Kesehatan Republik Indonesia. (2018). Hasil Utama Riset Kesehatan dasar. Jakarta: Departemen Kesehatan Republik Indonesia diakses tanggal 15 Nopember 2019 available on: https://www.persi.or.id/ analis

Departemen Kesehatan Republik Indonesia. (2009). Undang-Undang Tentang Kesehatan. Jakarta: Departemen Kesehatan Republik Indonesia

Pawestri, Ratih SW, Sonna M. (2013) Pengetahuan Sikap Perilaku Remaja Tentang Seks Pranikah, Jurnal Keperawatan Maternitas 1(1):46-54.

Pusat data dan Informasi Kementerian Kesehatan RI. (2015). Situasi Kesehatan Reproduksi Remaja. ISSN 2442-7659

Siswanto AW.(2014) Kebijakan Universal Health Coverage untuk pelayanan KB dan Kesehatan Reproduksi dan Dinamika Kependudukan Indonesia. Dipresentasikan dalam seminar kependudukan 4 Mei 2016 